\title{
Erratum to Fu's subcutaneous needling versus massage for chronic non-specific low-back pain: a randomized controlled clinical trial
}

\section{Editorial Office}

Annals of Palliative Medicine

Correspondence to: Editorial Office. Annals of Palliative Medicine. Email: apm@amepc.org.

Submitted Dec 27, 2021. Accepted for publication Jan 11, 2022.

doi: 10.21037/apm-2021-11

View this article at: https://dx.doi.org/10.21037/apm-2021-11

Erratum to: Ann Palliat Med 2021;10:11785-97

This article (1) titled "Fu's subcutaneous needling versus massage for chronic non-specific low-back pain: a randomized controlled clinical trial" (Ann Palliat Med 2021;10:11785-97; doi: 10.21037/apm-21-2986), unfortunately contained a mistake on page 11790 in the second paragraph of the results section. Namely, the sentence "The proportion of male patients in the FSN group was 57.7\%" should be corrected as "The proportion of male patients in the FSN group was 50\%". The authors confirm that this mistake does not affect the result and conclusion of the article.

Click here to view the updated version of the article.

Open Access Statement: This is an Open Access article distributed in accordance with the Creative Commons AttributionNonCommercial-NoDerivs 4.0 International License (CC BY-NC-ND 4.0), which permits the non-commercial replication and distribution of the article with the strict proviso that no changes or edits are made and the original work is properly cited (including links to both the formal publication through the relevant DOI and the license). See: https://creativecommons.org/licenses/by-nc$\mathrm{nd} / 4.0 \%$.

\section{References}

1. Ma KL, Zhao P, Cao CF, et al. Fu's subcutaneous needling versus massage for chronic non-specific low-back pain: a randomized controlled clinical trial. Ann Palliat Med 2021;10:11785-97.

Cite this article as: Editorial Office. Erratum to Fu's subcutaneous needling versus massage for chronic non-specific low-back pain: a randomized controlled clinical trial. Ann Palliat Med 2022;11(2):971. doi: 10.21037/apm-2021-11 